\title{
Implementation of Recycling Municipal Solid Waste (MSW) at University Campus
}

\author{
Tiew Kian-Ghee, Noor Ezlin Ahmad Basri, \\ Hassan Basri, Shahrom Md Zain and Sarifah Yaakob
}

Additional information is available at the end of the chapter

http://dx.doi.org/10.5772/45825

\section{Introduction}

Conventional waste disposal meets its limits throughout most of the world with increasing waste generation and rising proportions of packaging and toxic compounds in MSW. Landfill of waste leads to pollutant emissions over long periods of time, aggravated with the recent occurring of water pollution caused by open dumping at Sungai Kembong, Bangi (Utusan Malaysia Online, 2010 \& David, 2001), thus, requires sophisticated emission control and treatment methods. The consequences are long after-care periods for abandoned landfills. Furthermore, in many countries it is increasingly more difficult to find suitable locations for landfills, which are accepted by the population. In addition, the cost of management and transportation for waste is increasing with population. These circumstances are to be found all over the world and make new strategies for waste management necessary. The promotion of waste minimization and recycling are important components of modern waste management strategies. Nevertheless, even when the minimization and recycling potentials are fully exploited, there is still a residual fraction, which has to be disposed of. The burdens resulting from landfill can be minimized by pretreating the waste and thus limiting its emission potential. Malaysia, with a population of over 24 million generates 18,000 tones of domestic waste daily. In 2005, the per capita generation of solid waste in Malaysia varies from 0.45 to $1.44 \mathrm{~kg} /$ day depending on the economic status of an area (Agamuthu et. al 2009). There are now 168 disposal sites but only 7 are sanitary landfills. The rest are open dumps and about $80 \%$ of these dumps have filled up to the brim and have to be closed within two years (Mageswari 2005). Fauziah and Agamuthu (2007) reported that the MSW generation rate in Peninsular Malaysia is 
approximately $1.2 \mathrm{~kg} /$ capita.day. The same authors further stated that the current municipal generation rate in Malaysia has reached $1.3 \mathrm{~kg} / \mathrm{capita}$.day (Agamuthu and Fauziah, 2008).

The concept of 3R's (Reduce, Reuse, Recycle) is gaining importace as a sustainable and environmental friendly method. Recycling is one way to solving the problems of shortage of sanitary landfill (Chamhuri Siswar et al. 2000). On the other hand, composting is widely being practised at other developing countries (Hoornweg et al. 1999). Domestic waste generated in Malaysia is more than $40 \%$ is organic waste and overall in Malaysia, the waste composition is approximately $45 \%$ food waste, $24 \%$ plastic waste, $7 \%$ paper waste, $6 \%$ metal waste, 3\% glass waste and others (Japan International Cooperation Agency (JICA), 2006). Hence, the $45 \%$ food waste can be treated by composters to generate fertilizer and reduce the quantity of food waste directly dumped to the sanitary landfill. Solid waste management (SWM) is a complicated management this is because a lot outside factors will reflected it and normally reflected by culture, economy, food and topography (Shekdar, 2009). Hence, comprehensive study of solid waste management is needed before implementing suitable integrated waste management technology. Therefore, this paper presents the study on waste generation and composition at UKM and the evaluation on the effectiveness of recycling facilities provided being provided to divert waste from landfill.

\subsection{Background of case study}

Universiti Kebangsaan Malaysia, UKM (the National University of Malaysia) was officially established on 18 May 1970. The main campus of UKM is located at Bandar Baru Bangi, Selangor and consist 12 faculties, 12 centres and 14 institutes. UKM is one of the leading universities in Malaysia with a campus population of approximately 30,000, consists of majority of students, academic and supporting staff. In view of the size of this community, solid waste management represents a major challenge in achieving institutional sustainability. In 2008, a major change took place in the solid waste management (SWM) system in the university. A Memorandum of Agreement (MoA) was signed to upgrade collection of solid waste to a centralized collection system through collaboration between the university and the solid waste company Alam Flora Sdn. Bhd. (AFSB). The collaboration intended to institute integrated solid waste management (ISWM) at the university and enable the university to achieve a Zero-Waste campus objective.

\section{Materials and methods}

\subsection{Waste generation, waste composition and waste characterization}

Daily waste generation was carried out based on the weight of solid waste collected by the waste collector company Alam Flora Sdn Bhd (AFSB). The following shows the segregation methods done at the UKM campus:- 


\subsubsection{Source segregation (24 $4^{\text {th }}$ February 2009 to $2^{\text {nd }}$ March 2009)}

The samples were taken from four different categories of generation: (1) faculties (excluding laboratories), (2) dormitories (including cafeteria), (3) offices, and (4) student affairs. These four categories are representative because they cover all the activities carried out at the campus. The characterization of the solid waste was carried out using the modified Methodology for Conducting Composition Study for Discarded Solid Waste (University of Central Florida, 1996). Samples were taken during 7 consecutive days (including Sundays). For the composition analysis, the samples were classified manually into two categories i.e. recyclable items (papers, plastics, metals and glass) and non-recyclable items (food waste, ewaste and others). The results from the solid waste samples were analyzed. The weight percentage for each subcategory was calculated using the following equation:

Sub - category percentage $=($ Amount of sub - category, in kg / Total weight, in $\mathrm{kg}) \times 100 \%$

\subsubsection{Centralized segregation ( $27^{\text {th }}$ July 2009 to $23^{\text {th }}$ August 2009)}

All baseline characterizations were performed according to the ASTM 5231-92 Standard Test Method for Determination of the Composition of Unprocessed Municipal Solid Waste (ASTM, 2003) and LAGA PN 98 (RFA, 2001). During these four weeks the sampling was done every Monday, Wednesday and Saturday by cone Sampling. At first the samples were taken from a heap and later out of a roro-container. Through the use of a wheelbarrow, public works employees and master course students moved about $450 \mathrm{~kg}$ of MSW onto the thin plastic sheet. Ripping and opening of the plastic bags and containers ensued with small knives, and mixing was achieved with shovels and rakes. Then the large sample was quartered so that approximately one fifth of the sample $(91-136 \mathrm{~kg}$ ) was left to form a representative sample. Finally, manual sorting of the waste was done according to ASTM categories i.e. plastic bag, plastic bottle, polystyrene, mixed plastic (consists hard plastic), non-recyclable plastic bag (black plastic bag), paper (newspaper, magazines, cardboard and box), aluminum, rubber and leather, food waste (cooked waste and raw materials), and glass as shown in Fig. 1., and different types of samples were placed into properly labeled buckets.

\subsection{Recycling facilities}

Recycling facilities at UKM consist of a recycling center, paper recycling boxes in all offices, and 2-bins recycling system at strategic locations throughout the campus.

\subsubsection{Paper recycling boxes}

Paper recycling boxes are being provided to all offices throughout the campus. The study on the effectiveness of office paper recycling was carried out from April 2010 to October 2010. Monthly data on the collected recycled papers is provided by Alam Flora Sdn. Bhd. Fig. 2. shows paper recycling boxes being located in an office at UKM. 


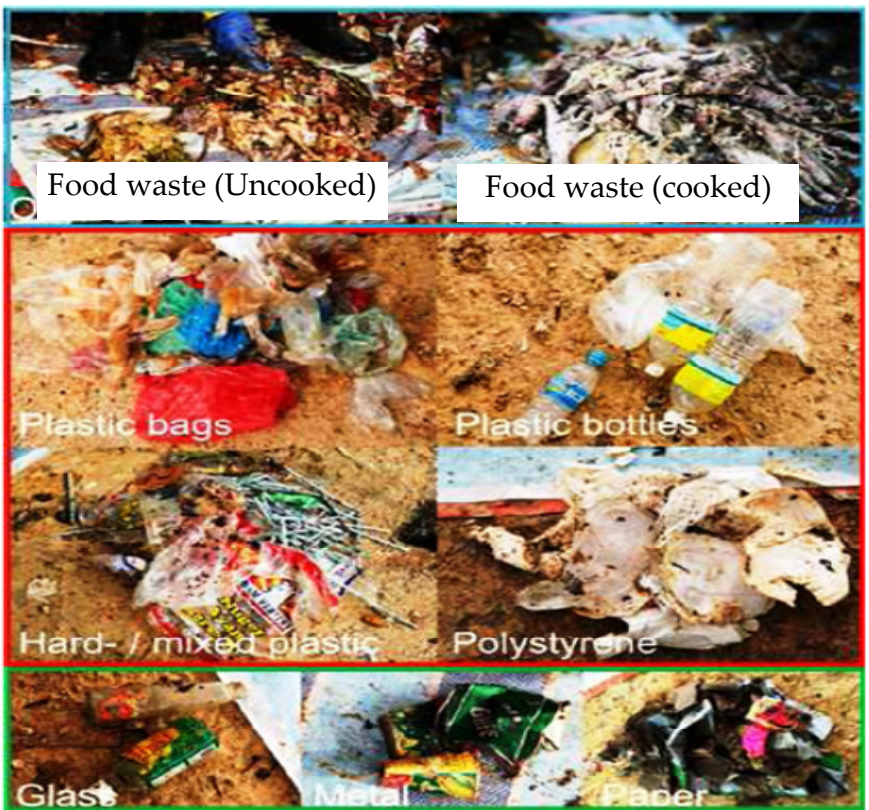

Figure 1. Waste composition categories.

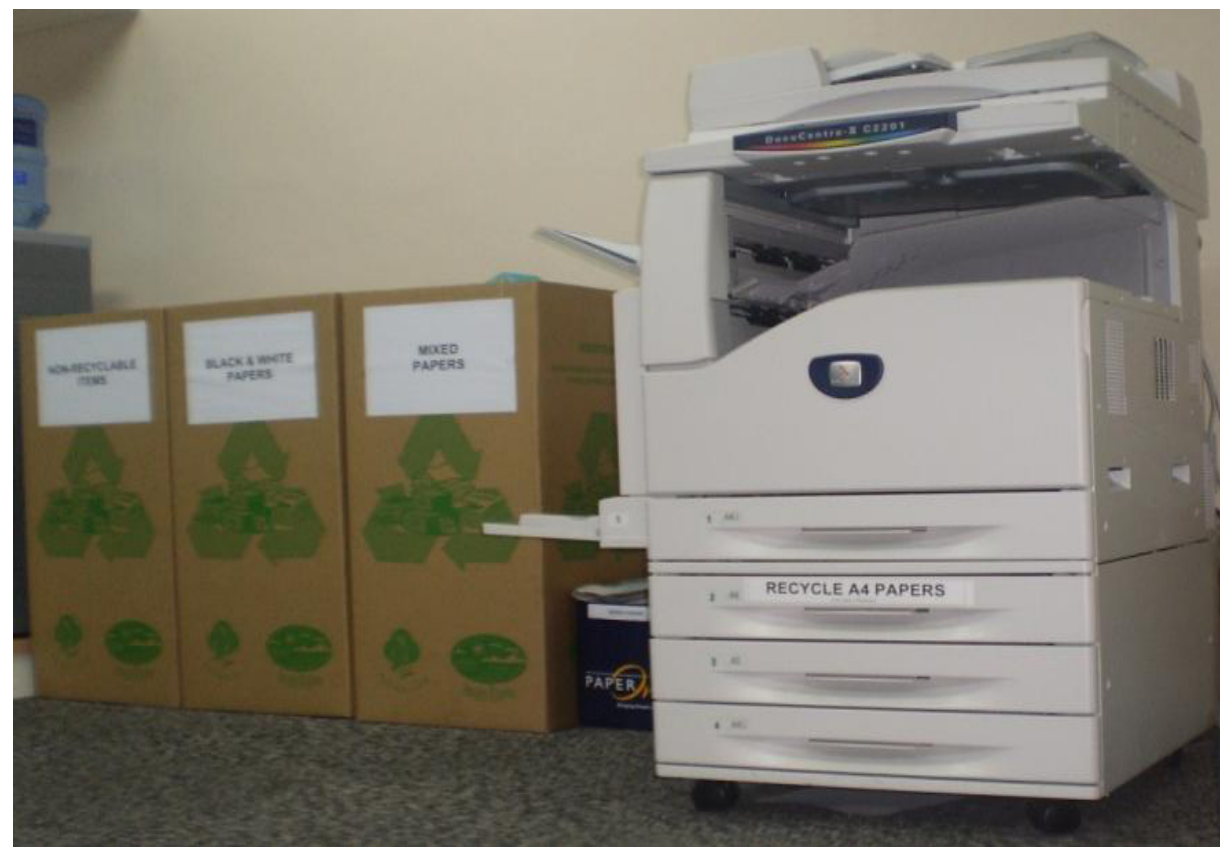

Figure 2. Paper recycling box in an office at UKM 


\subsubsection{Recycling centre}

The recycling centre at UKM is located nearby the main entrance of the university. It had started its operation since April 2010, initially every first Tuesday for the month, but had increased to every Tuesday of the month. Alam Flora Sdn. Bhd. is responsible to buy the recyclable items collected from the Recycling Centre. The Recycling Center is also being used as a centre to educate UKM community on the importance of recycling to reduce the burden on landfills. The study on the effectiveness of the recycling was carried out from April 2010 till October 2010. Monthly data on the recyclable items is provided by Alam Flora Sdn. Bhd. Fig. 3. shows the front view of the Recycling Centre, while Fig. 4. shows the five compartments for different categories recyclable items.

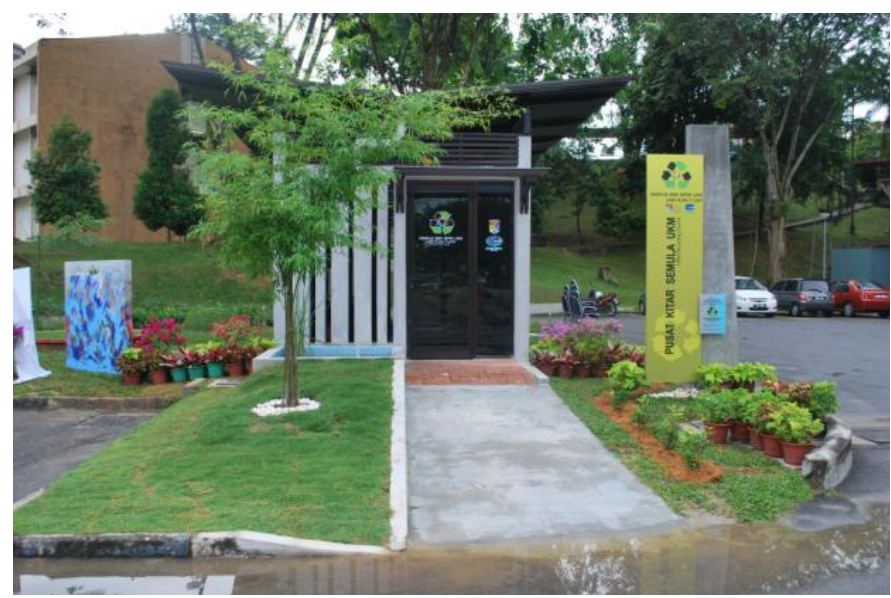

Figure 3. The front view of the Recycling Centre

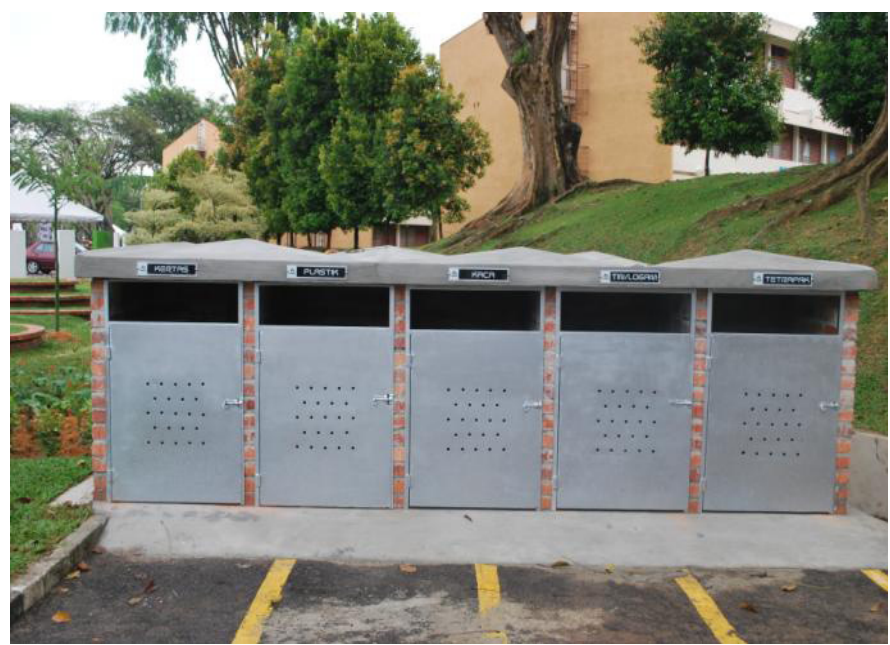

Figure 4. Five compartment for different categories of recycled items 


\subsubsection{2-Bins recycling system}

The study on the effectiveness for the 2-bins recycling system at UKM was done at the Faculty of Engineering and Built Environment (FKAB). The orange coloured bin is for commingled recyclable items and the other bin is for non-recyclable waste. The recyclable items in the recycling bins were weighted. Ten waste stations were observed in the fourstorey academic building at FKAB. The 2-bins recycling system consists of two types of container, which are a bin for commingled recycling items and a bin for mixed nonrecyclable waste as shown in Fig. 5. In addition, the attitudes and acceptance of students were also being evaluated.

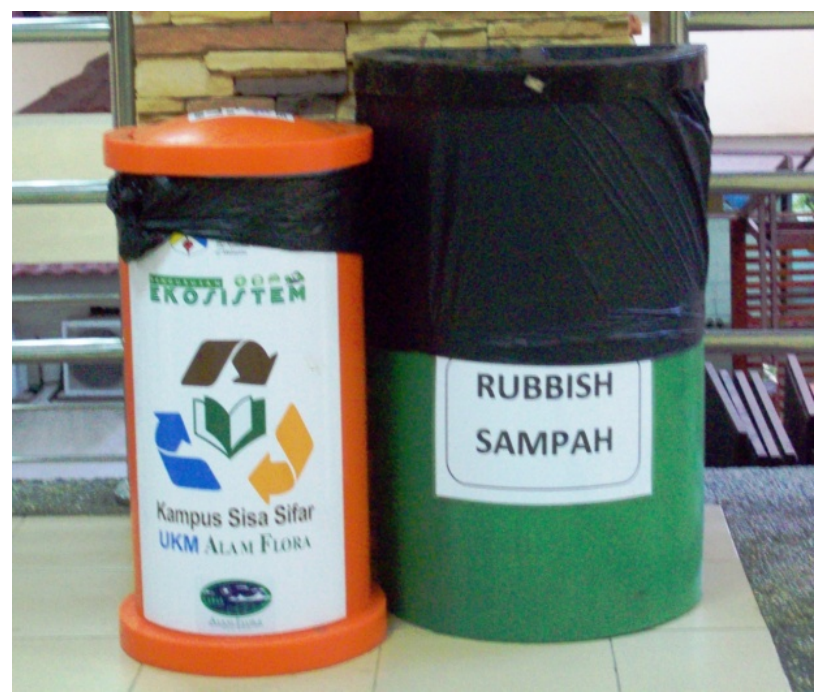

Figure 5. 2-bins recycling system located at the FKAB

\section{Results and discussions}

\subsection{Waste generation}

The highest monthly waste generation was in July 2009 due to the new semester intake for students. The waste generation in September 2009, which is during a week study period and also the fasting month of Ramadhan for the Muslims is the lowest in comparison to other months. Waste generation in December 2009 and January 2010 was low as well due to the semester break for the students. Results in Table 1 shows the average daily waste generation at UKM campus is approximately 4.76 ton/day. 


\begin{tabular}{ccc}
\hline Month & $\begin{array}{c}\text { Total waste generation } \\
\text { (ton/month) }\end{array}$ & $\begin{array}{c}\text { Average daily waste generation } \\
\text { (ton/day) }\end{array}$ \\
\hline July 2009 & 176.63 & 5.70 \\
August 2009 & 156.64 & 5.22 \\
September 2009 & 128.09 & 4.27 \\
October 2009 & 169.85 & 5.66 \\
November 2009 & 145.14 & 4.84 \\
December 2009 & 112.22 & 3.62 \\
January 2010 & 105.69 & 3.41 \\
February 2010 & 145.60 & 5.20 \\
March 2010 & 151.28 & 4.88 \\
\hline
\end{tabular}

Table 1. Waste generation at campus UKM, Bangi

\subsection{Waste composition}

From the waste composition study at UKM by applying the segregation method at source showed that food waste is the highest portion originating from various locations, i.e. Dormitories (51.6\%), Faculties (57.8\%), Student Affairs Building (56.4\%), and Offices (53.7\%) as shown in Table 2. The percentage of plastic items is the second highest for Dormitories $11.8 \%$ and Faculties $12.7 \%$, however, at Student Affairs Building is $13.3 \%$ and Offices is $10.9 \%$. For both Student Affairs Building and Offices, the second highest amount of recyclable items is papers, i.e. Student Affairs Building, $17.7 \%$ and Offices $25.5 \%$.

\begin{tabular}{cccccc}
\hline & Dormitories & Faculties & $\begin{array}{c}\text { Student Affairs } \\
\text { Bldg }\end{array}$ & Offices & Average* $^{*}$ \\
\hline Papers & $8.3 \%$ & $12.0 \%$ & $17.7 \%$ & $25.5 \%$ & $15.9 \%$ \\
Plastics & $11.8 \%$ & $12.7 \%$ & $13.3 \%$ & $10.9 \%$ & $12.2 \%$ \\
Metals & $1.9 \%$ & $0.9 \%$ & $0.4 \%$ & $1.5 \%$ & $1.2 \%$ \\
Glass & $0.2 \%$ & $0.6 \%$ & $1.8 \%$ & $0.1 \%$ & $0.7 \%$ \\
Food Waste & $51.6 \%$ & $57.8 \%$ & $56.4 \%$ & $53.7 \%$ & $54.9 \%$ \\
e-Waste & $0.1 \%$ & $0.2 \%$ & $0.3 \%$ & $0.3 \%$ & $0.2 \%$ \\
Others & $26.2 \%$ & $15.8 \%$ & $10.1 \%$ & $7.9 \%$ & $15.0 \%$ \\
Total & $100.0 \%$ & $100.0 \%$ & $100.0 \%$ & $100.0 \%$ & $100.0 \%$ \\
\hline
\end{tabular}

Table 2. Summary waste composition for segregation by source method

In terms of recyclable materials, the study showed that overall approximately $30 \%$ of major recyclable materials were disposed of from the campus, this includes mainly papers $(15.9 \%)$, plastics $(12.2 \%)$, glasses $(0.7 \%)$, and metals (include ferrous metals, non-ferrous metals and some aluminium) (1.2\%). Offices generated the highest percentage of recyclable items, followed by Student Affairs Building, Faculties and Dormitories. 
Waste composition by the centralised method was carried out for a period of one month, and at the end the total number of samples collected was 12. Table 3 showed waste composition results from the centralised method. The food waste constitutes the highest amount in all categories which is $42.95 \%$, i.e. $27.79 \%$ for cooked food waste and $15.16 \%$ for raw materials of food waste. Currently, approximately $30.55 \%$ of major recyclable materials were disposed off at landfills. The recyclable materials consist of mixed papers and plastics, plastic bottles, glasses, and metals. Some other wastes recorded were polystyrene container $(5.48 \%)$, non-recyclable plastic bags (the black plastic garbage bag) $(6.26 \%)$ and rubber and leather wastes $(1.37 \%)$.

\begin{tabular}{|c|c|c|}
\hline Types & Amount (kg) & $\%$ \\
\hline Plastic Bag & 14.5 & 13.39 \\
\hline Plastic Bottle & 1.4 & 1.33 \\
\hline Polystyrene & 5.9 & 5.48 \\
\hline Mixed Plastic & 10.3 & 9.56 \\
\hline Non-recyclable Plastic Bag & 6.8 & 6.26 \\
\hline Newspaper, Magazines, Cardboard and Box (Papers) & 18.6 & 17.18 \\
\hline Aluminum Cans (Metals) & 1.9 & 1.72 \\
\hline Rubber and Leather & 1.5 & 1.37 \\
\hline Cook (Food Waste) & 30.1 & 27.79 \\
\hline Uncook (Food Waste) & 16.4 & 15.16 \\
\hline Glass & 0.8 & 0.76 \\
\hline Total & 108.2 & 100.00 \\
\hline
\end{tabular}

Table 3. Waste composition by centralized method in campus UKM, 2009

The centralised segregation method showed a much higher proportion of plastic items (36.02\%) as compared to the source segregation method $(12.20 \%)$ as shown on Table 4 . The moisture content is higher in the centralized segregation method as compared to the sample collected directly from the garbage bins. The higher moisture content is due to the waste samples for the centralised segregation is obtained from compactor trucks, which normally being placed outside buildings for at least one night, thus rainwater may get into the waste during storage. Further, in a compactor truck all types of waste including the wet food waste will be mixed and compacted.

Other waste components showed almost the same percentage, except source segregation method had a higher amount of others waste component, which is $15.2 \%$, while centralized segregation method is nil. Other waste category consists of bulky wastes and some miscellaneous items. In the segregation at source method, everything that was set out as waste was treated as sample, and this item is significant, while the centralized segregation method, the sample was taken from the collection vehicle, which does not collect bulky 
waste. This is probably the main reason for the difference. The benefit of studying the two methods for waste segregation is to determine the waste composition generated at source and at the end management.

\begin{tabular}{lccc}
\hline & Source Segregation UKM, 2009 & $\begin{array}{c}\text { Centralized Segregation } \\
\text { UKM, 2009 }\end{array}$ & Average \\
\multicolumn{1}{c}{ Types } & \% & \% & \% \\
\hline Plastics & 12.20 & 36.02 & 24.11 \\
Papers & 15.90 & 17.18 & 16.54 \\
Metals & 1.20 & 1.72 & 1.46 \\
Rubber \& Leather & - & 1.37 & 0.68 \\
Food Waste & 54.90 & 42.95 & 48.92 \\
Glass & 0.70 & 0.76 & 0.73 \\
Others & 15.20 & - & 7.6 \\
Total & 100 & 100 & 100 \\
\hline
\end{tabular}

Table 4. Comparison waste composition UKM between segregation by source method and centralized segregation method

\subsection{Effectiveness of the recycling facilities}

\subsubsection{Paper recycling boxes}

Paper recycling boxes in offices on UKM campus, Bangi had begun in March 2010. Collection of recyclable papers was conducted in April 2010 to present. A total of 293 paper recycling boxes had been placed in 62 locations, which include institutes, centers, faculties and libraries. The results of recyclable papers collection rate is increasing from month to month. Although in Fig. 6 shows a decline in August (975kg) as compared to July (3,250 kg) with a difference of $2,275 \mathrm{~kg}$ because August is semester intake but July is end of short semester. Hence, a lot of materials have been thrown on end of semester compared to semester intake. However, an increasing trend can be seen in comparison to April $(809 \mathrm{~kg})$ which is first collection of paper recycling program at offices. Detailed recyclable items composition consists of $46 \%$ black and white paper, 32\% mixed paper and $18 \%$ newspapers as shown in Fig. 7.

A total of 11,733 kg paper waste generated by UKM offices had been recycled from April 2010 to October 2010. Coordinators for recycling of office's paper programme were appointed to play important role in the management of paper recycling in offices under the supervision of the Department of Development Management, UKM (JPP). 


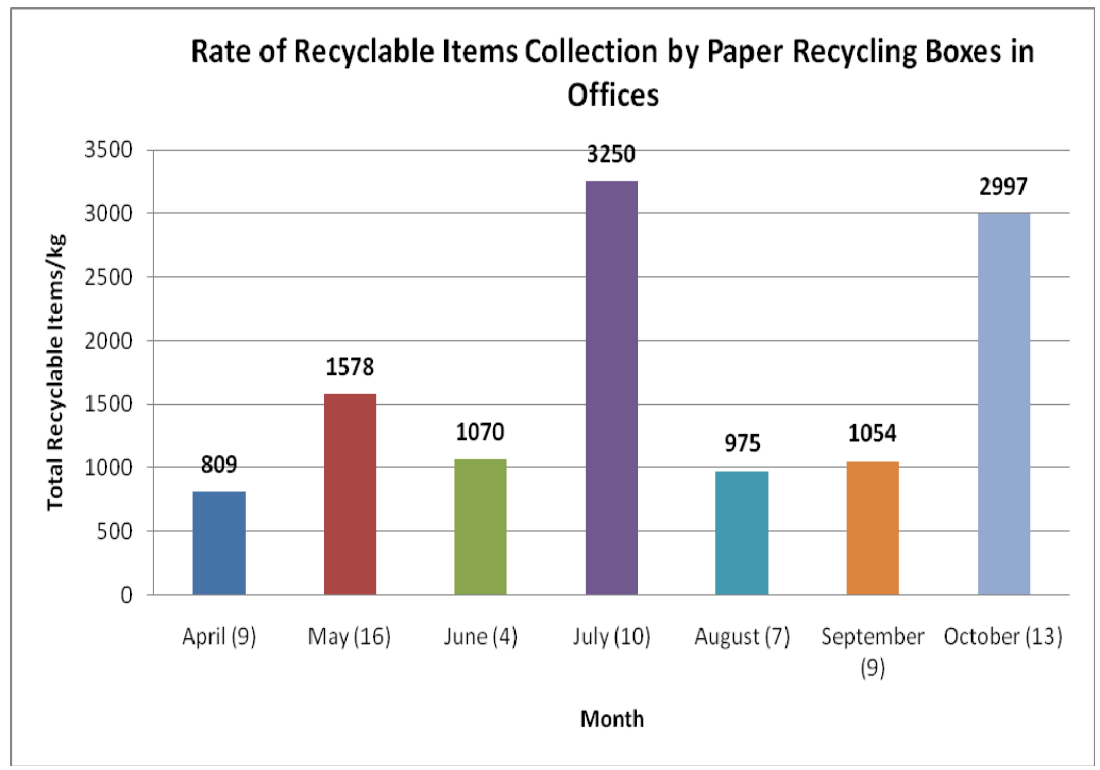

Figure 6. Recycling rate of recyclable papers in paper recycling boxes.

\section{Recyclable Items Composition (Paper Recycling Boxes in Offices)}

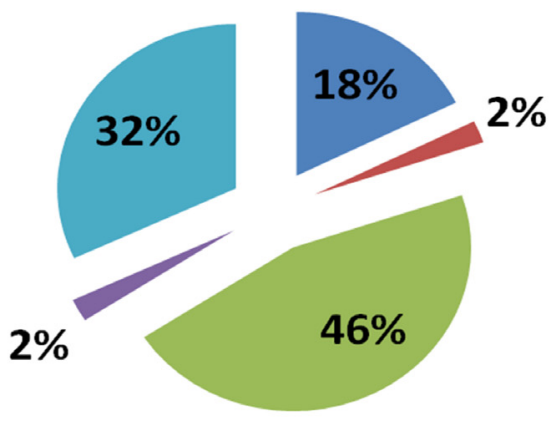

- Old Newspaper

Magazine

Black \& While

Paper

Boxes

Mixed Paper

Figure 7. Detailed composition of recyclable papers from paper recycling boxes

\subsubsection{Recycling centre}

Fig. 8 shows the collection rate at the Recycling Center from April to October 2010. A total of $4,008 \mathrm{~kg}$ of recyclable materials from April 2010 to October 2010 was collected. The recyclable items composition is $28.52 \%$ newspapers, $27.22 \%$ black and white paper, $16.47 \%$ mixed paper, $8.43 \%$ magazines, $6.29 \%$ boxes, $5.41 \%$ plastics and $4.17 \%$ can, as shown in Fig. 9 . 


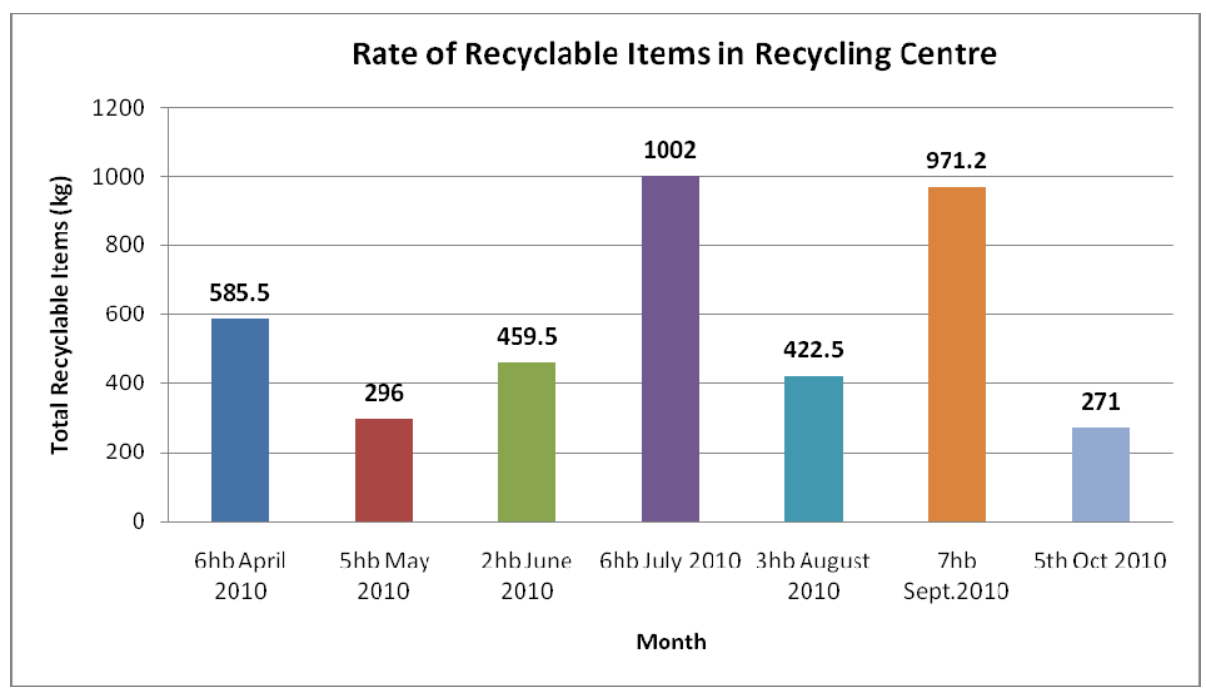

Figure 8. Monthly collection rate of recyclable items at the Recycling Centre

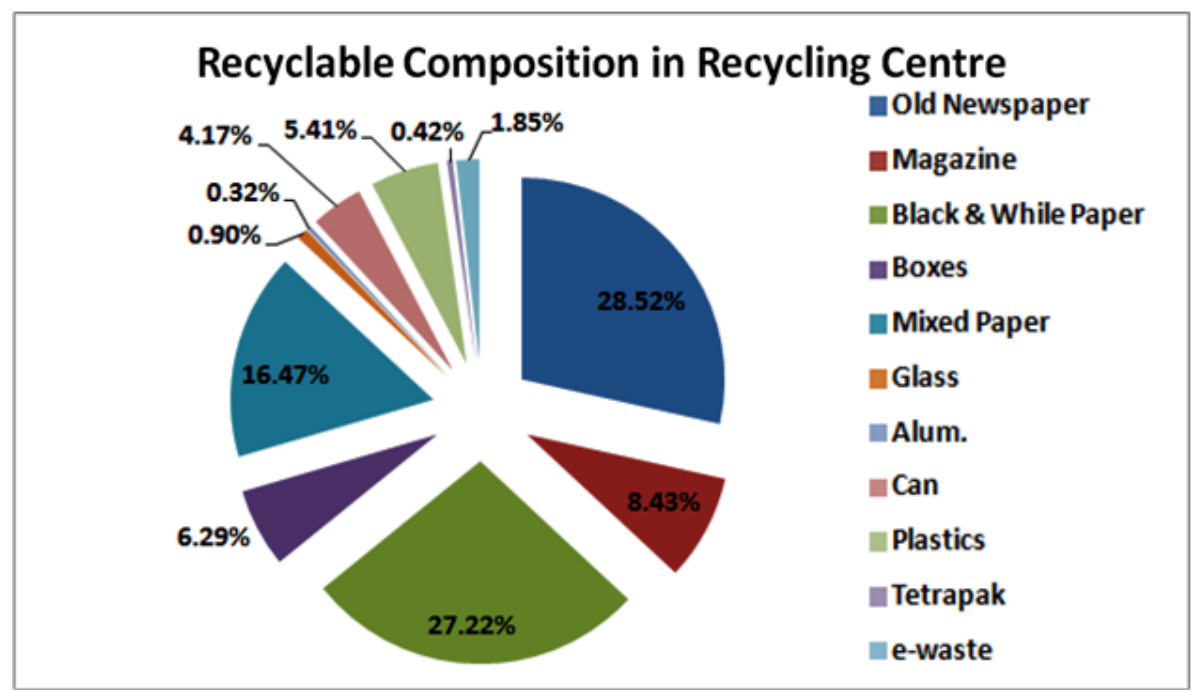

Figure 9. Recyclable items composition at the Recycling Centre

\subsubsection{2-Bins recycling system}

From Fig. 10, the 2-bins recycling system at faculties shows that the usage of the recycling bins still needed improvement due to $65.3 \%$, which is slightly more than half of the content in the orange bin (consists of commingled recyclable items) was recyclable items while $34.7 \%$ was non-recyclable items. There is still high amount of non-recyclable items were wrongly placed $(34.7 \%)$ in the orange bin. This shows that, publicity and awareness 
programs are required to educate the staffs and students on the correct usage of the orange bins. On the other hand, for the mixed waste bins, the content was $58.7 \%$ non-recyclable items while the percentage for recyclable items was $41.3 \%$. Thus, this also shows a high percentage of wrong usage for the mixed waste bins (41.3\%).

From the study, the 2-bins recycling system is appropriate to ensure students to separate the recyclable items. Many researchers showed that the compliance is increasing when recycling bins are placed closer to users, and the physical features of the bins will also influence the recycling compliance (Sean Duffy \& Michelle Verges, 2009). For this study, orange coloured bins with colourful design were specially made for recycling bins at UKM campus and being placed in the areas which easily accessible by the users.

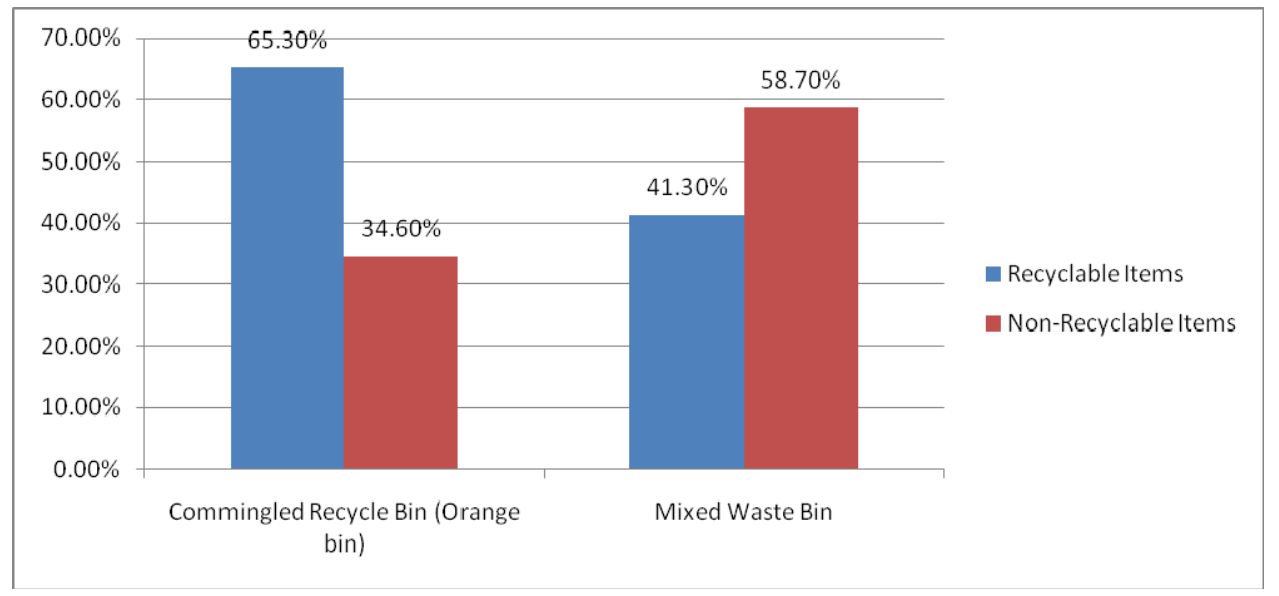

Figure 10. Summary of 2 bins system in FKAB, UKM

\section{Conclusions}

The results showed that the percentage of food waste generated from UKM campus is the highest, which is $54.9 \%$ (source segregation method) and $42.95 \%$ (centralized segregation method). Plastics waste is the second highest portion in the waste composition. This is due to the habit of students who prefer to buy food from cafeteria but dine at home, hence, high usage of polystyrene container, drinking plastic bottles and plastic bags used for packaging materials. Papers waste is also in high proportion in the waste composition. This is due to UKM campus being an education institution. From the study, most of the recyclable items could be recovered by providing appropriate recycling facilities along with publicity and the awareness programme. The results showed that waste diversion from landfill is $1.62 \%$ by Paper Recycling Boxes at offices and the Recycling Centre. The implementation of recycling MSW at the university campus has the potential to reduce waste disposal to landfills and thus making Universiti Kebangsaan Malaysia a sustainable campus. Finally, sustaining the recycling facilities is vital to ensure the success of continuous recycling programme at UKM campus. 


\section{Author details}

Tiew Kian-Ghee

Faculty of Engineering and Built Environment, University Kebangsaan, Malaysia

Noor Ezlin Ahmad Basri, Hassan Basri and Shahrom Md. Zain

Faculty of Engineering \& Built Environment,

Department of Civil and Structural Engineering, University Kebangsaan, Malaysia

Sarifah Yaakob

Alam Flora Sdn Bhd., Malaysia

\section{Acknowledgement}

The authors are grateful to Universiti Kebangsaan Malaysia for funding the project (Grant code: UKM-PTS-007-2009) and Alam Flora Sdn Bhd for the kind cooperation during the project.

\section{References}

Agamuthu, P. and Fauziah, S.H., 2008. Solid waste: environmental factors and health. Paper presented at EU-Asia Solid Waste Management Conference, EA-SWMC, Ipoh, 29-30 October 2008

Agamuthu, P., Fauziah Shahul Hamid \& Kahlil Khidzir. 2009. Evolution of solid waste management in Malaysia: Impacts and implications of the solid waste bill, 2007. J Mater Cycles Waste Management 11:96-103.

ASTM (American Society of Testing and Materials), 2003. Standard Test Method for Determination of the Composition of Unprocessed Municipal Solid Waste. Designation: D, pp. 5231-5292.

Chamhuri Siswar, Talylor, D. \& Hasnah Ali. 2000. Knowledge, attitudes and perception on minimising household municipal solid waste generation: a case of Petaling Jaya Municipality Council. Kertas kerja Bengkel Dasar Memperbaiki Pengurusan Sisa Pepejal Perbandaran. Anjuran Institut Alam Sekitar dan Pembangunan, Universiti Kebangsaan Malaysia. Bangi, Julai 1999 dan November 2000.

David, S.C. 2001. The McGraw-Hill Recycling Handbook. Characterization of waste streams, pg. 3.1-3.36. New York: McGraw Hill.

Fauziah, S.H. and Agamuthu, P. 2007. SWPlan Software Application for Malaysian Municipal Solid Waste Management. Malaysian Journal of Science, 26 (1). pp. 17-22. ISSN 13943065

Hoornweg, D., Thomas, L. \& Otten, L. 1999. Composting and its applicability in developing countries. Urban Waste Management.

http://www.worldbank.org/htm/fpd/urban/solid_wm/uwp8.pdf [5 Ogos 2009].

Japan International Cooperation Agency (JICA). 2006. The Study On National Waste Minimisation In Malaysia. Yachiyo Engineering Co., Ltd. \& Ex Corporation. 
Länderarbeitsgemeinschaft Abfall (RFA). 2001. LAGA PN 98 Richtlinie für das Vorgehen beiphysikalischen, chemischen und biologischen Untersuchungen im Zusammenhang mitder Verwertung/Beseitigung von Abfällen.

Mageswari, S. 2005. GIAI global meeting. Penang, Malaysia. 17-21.

Sean Duffy and Michelle Verges. 2009. It Matters a Hole Lot Perceptual Affordances of Waste Containers Influence Recycling Compliance. Environment and Behavior. Vol. 41, $5,741-749$.

Shekdar, A.V. 2009. Sustainable Solid Waste Management: An Integrated Approach for Asian Countries. Waste Management 29, Pages 1438-1448.

University of Central Florida. 1996. Methodology for Conducting Composition Study for Discarded Solid Waste.

Utusan Malaysia Online. 2010. "Loji rawat air Sg. Semenyih tercemar". http://www.utusan.com.my/utusan/info.asp?y=2010\&dt=0908\&pub=Utusan_Malaysia\& sec=Muka_Hadapan\&pg=mh_05.htm 